\title{
Editorial
}

\section{The Known and the Unknown about Oxygen Use}

\section{Hany Aly, MD}

Journal of Perinatology (2004) 24, 335-336. doi:10.1038/sj.jp.7211106

"A car does not run without gas, though it will not crash. The neonate cannot function without oxygen and will crash."

L. Stanley James - Babies and Children's Hospital of New York, 1955 to 1992.

It is interesting, as well as disturbing, to find wide variability in the use of oxygen $\left(\mathrm{O}_{2}\right)$ among neonatologists following discharge of premature infants from the hospital. ${ }^{1}$ Some physicians do not prescribe $\mathrm{O}_{2}$ unless pulse oximetery $\mathrm{O}_{2}$ saturation $\left(\mathrm{SPO}_{2}\right)$ of the premature infant is less than $84 \%$; while others recommend supplemental $\mathrm{O}_{2}$ when $\mathrm{SPO}_{2}$ is below $98 \%$. This wide variation in the use of $\mathrm{O}_{2}$ suggests that our knowledge about $\mathrm{O}_{2}$ is far from adequate.

Oxygen is, without a doubt, important for life. Even a short absence, can be disastrous, and can lead to long-term neurological consequences. Chronic hypoxia may lead to learning, cognitive, and attention disabilities when it occurs in utero as observed in small-for-date infants or postnatally as in children with congenital heart diseases. ${ }^{2,3}$ Oxygen is required for cell metabolism and for growth. Some physicians advocate use of "excess" oxygen to ensure proper oxygenation, weight gain and more regular breathing.

Still, an excess of oxygen is not safe. In 1954, Dr. William Silverman taught us a lesson with the discovery of an association between increased inspired $\mathrm{O}_{2}$ concentration $\left(\mathrm{FiO}_{2}\right)$ and retinopathy of prematurity (ROP). ${ }^{4}$ It had become fashionable in the 12 preceding years to provide supplemental $\mathrm{O}_{2}$ to establish regular rhythmic breathing in premature infants based on the then "current available" knowledge. Thousands of newborns developed blindness until it was discovered that using supplemental $\mathrm{O}_{2}$ was based on beliefs, not science. Premature infants, when supplied with excess $\mathrm{O}_{2}$ to sustain $\mathrm{SPO}_{2}>95 \%$, developed $\mathrm{O}_{2}$ dependency, bronchiopulmonary dysplasia (BPD) and pneumonia, without improving neurological outcomes when compared to $\mathrm{SPO}_{2}$ $<95 \%$.

George Washington University Hospital (H.Z.A), Washington DC, USA.

Address correspondence and reprint request to Hany Z. Aly, George Washington University Hospital, 900 23rd Streeet, N.W. Suite G2092, Room 9132 Washington DC 20037, USA.
Oxygen can also harm term infants. The use of oxygen for a brief period of time (median of $7 \mathrm{~min}$ ) during resuscitation of fullterm infants in the delivery room can cause an oxidative stress, detectable even a month following exposure to $\mathrm{O}_{2}{ }^{8}$ Supplemental oxygen use in infants with severe persistent pulmonary hypertension, and need for extracorporeal membrane oxygenation, is associated with abnormal pulmonary mechanics when measured at 10 to 15 years of age. The severity of these pulmonary changes correlates significantly with the duration of exposure to supplemental $\mathrm{O}_{2}{ }^{9}{ }^{9}$

At the cellular level, oxidative damage to the lung proteins has been quantified in ventilated neonates through measurement of carbonyl groups in samples suctioned from their tracheas. ${ }^{10}$ of course, damage is not limited only to the lung. A significant increase of carbonyl proteins has also been detected in the liver of rats exposed to hyperoxia. ${ }^{11}$

Several health problems are thought to occur in relation to oxygen radicals. The pathogenesis of BPD, ROP and ischemiareperfusion injury in neonates, as well as arthritis, atherosclerosis, cataractogenesis, hypertension and the normal aging of adults involves oxygen-induced cellular damage. ${ }^{12}$ Therefore, researchers proposed antioxidants for the protection against some diseases; such as the use of vitamin $\mathrm{E}$ for the prevention of ROP, the trials of vitamin $C$ in hypoxic-ischemic injury and superoxide dismutase for the amelioration of the course of BPD. It seems reasonable to use $\mathrm{O}_{2}$ in moderation, rather than counteract its adverse effects. A clinical example of this $\mathrm{O}_{2}$ moderation is the use of room air, instead of $100 \% \mathrm{O}_{2}$, for neonatal resuscitation in the delivery room. This strategy did not appear to compromise somatic or neurologic growth when assessed at 18 to 24 months of age. ${ }^{13}$ Another example relates to the introduction of a neonatal unit-based policy to closely monitor and control for any excessive use of $\mathrm{O}_{2}$. Such a unit reported substantial success in decreasing the incidence of severe ROP by five-folds. ${ }^{14}$

Physiologically, $\mathrm{O}_{2}$ is present in room air as a small fraction $\left(21 \%, \mathrm{P}_{\mathrm{i}} \mathrm{O}_{2}=150 \mathrm{mmHg}\right)$ at sea level. It is then further diluted en route to the alveoli with expiratory gas to lower $\mathrm{P}_{\mathrm{A}} \mathrm{O}_{2}$ to $100 \mathrm{mmHg}$ $\left(\mathrm{F}_{\mathrm{A}} \mathrm{O}_{2}\right.$ almost $\left.14 \%\right)$. Imagine how much more efficient breathing would be if the alveoli had direct contact to air, without airways or dead space, or even if alveoli could breathe pure $100 \% \mathrm{O}_{2}$. But of course this does not happen, and for a good reason.

The newborn gets into trouble only when born prematurely. Should they continue until full gestation, BPD, ROP and other diseases would disappear. The impact of environmental change in the development of diseases in these premature infants is obvious. Practitioners have many tools to simulate the fetal environment: 
keeping isolettes dark, minimizing noise levels in the nursery, and carefully commencing enteral feeding. Fetal $\mathrm{SPO}_{2}$ is around $70 \%$, thus significantly lower than $\mathrm{SPO}_{2}$ in the full term. Where should we keep $\mathrm{SPO}_{2}$ in the very small premature infants? Even today, the answer is we do not know. In the absence of well-designed trials to correlate clinical outcomes in the premature infants at different gestational ages, with $\mathrm{SPO}_{2}$, this issue is still open. We should admit that we do not know the correct answer.

It is equally dangerous to depend on "the currently available" anecdotal experiences and opinions of "experts." Premature infants delivered in the $1940 \mathrm{~s}$ were the victims of "currently available experience", with liberal use of $\mathrm{O}_{2}$. Physicians still greatly rely on anecdotal experiences to treat different disease states. A clear example of that practice is the use of a hyperventilation, hyperoxygenation strategy when managing infants with persistent pulmonary hypertension of the newborn. ${ }^{15}$ Ultimately, facts when they emerge, may fundamentally differ from these practices and opinions of today. Therefore, we need to search for the truth and have the issue of $\mathrm{O}_{2}$ use as a priority to resolve, before embarking on using new machines or drugs.

\section{References}

1. Ellsbury DL, Acarregui MJ, McGuinness GA, Eastman DL, Klein JM. Controversy surrounding the use of home oxygen for premature infants with bronchopulmonary dysplasia. J Perinatol. 2004;24:36-40.

2. O'Keeffe MJ, O'Callaghan M, Williams GW, Naiman JM, Bor W. Learning, cognitive, and attentional problems in adolescents born small for gestational age. Pediatrics 2003;112:301-7.

3. Mahle WT. Neurologic and cognitive outcomes in children with congenital heart disease. Curr Opin Pediatr 2001; 13: 482-6.
4. Silverman WA. A cautionary tale about supplemental oxygen: the albatross of neonatal medicine. Pediatrics 2004;113:394-6.

5. Wilson JL, Long SB, Howard PJ. Respiration of premature infants: response to variations of oxygen and to increased carbon dioxide in inspired air. Am J Dis Child 1942;63:1080-5.

6. Supplemental therapeutic oxygen for prethreshold retinopathy of prematurity (STOP-ROP), a randomized controlled trial. I. Primary outcomes. Pediatrics 2000; 105: 295-310.

7. Askie LM, Henderson-Smart DJ, Irwig L, Simpson JM. Oxygen-saturation targets and outcomes in extremely preterm infants. $\mathrm{N}$ Engl J Med 2003;349:959-67.

8. Vento M, Asensi M, Sastre J, Garcia-Sala F, Pallardo FV, Vina J. Resuscitation with room air instead of $100 \%$ oxygen prevents oxidative stress in moderately asphyxiated term neonates. Pediatrics 2001;107: $642-7$.

9. Boykin AR, Quivers ES, Wagenhoffer KL, et al. Cardiopulmonary outcome of neonatal extracorporeal membrane oxygenation at ages 10-15 years. Crit Care Med 2003;31:2380-4.

10. Gladstone IM, Levine RL. Oxidative proteins in neonatal lungs. Pediatrics 1994;93:764-8.

11. Strake PE, Oliver CN, Stadtman ER. Modification of hepatic proteins in rats exposed to high oxygen concentration. FASEB J 1987;1:36-9.

12. Halliwell B, Guteridge JMC. Role of free radicals and catalytic metal ions in human disease: an overview. Methods Enzymol 1990;186: $1-85$.

13. Saugstad OD, Ramji S, Irani SF, et al. Resuscitation of newborn infants with $21 \%$ or $100 \%$ oxygen: follow-up at 18 to 24 months. Pediatrics 2003;112:296-300.

14. Chow LC, Wright KW, Sola A. Can changes in clinical practice decrease the incidence of severe retinopathy of prematurity in very low birth weight infants? Pediatrics 2003;111:339-45.

15. Fox WW, Duara S. Persistent pulmonary hypertension of the neonate: diagnosis and management. J Pediatr 1983;103:505-14. 